\title{
Quantification of biomass and litter in agroforestry system with sour orange cultivation in the Brazilian Amazon
}

Quantificação da biomassa e liteira em sistema agroflorestal com o cultivo da laranja azeda na Amazônia brasileira

Cuantificación de la biomasa y la hojarasca en la agroforestería con cultivo de naranja agria en la Amazonia brasileña

Pedro Paulo da Costa Alves Filho

ORCID: https://orcid.org/0000-0002-5945-5515 Universidade Federal Rural da Amazônia, Brazil E-mail: pp.alvesfilho@outlook.com

Osvaldo Ryohei Kato

ORCID: https://orcid.org/0000-0002-2422-9227 Embrapa Amazônia Oriental, Brazil

E-mail: osvaldo.kato@embrapa.com.br

Jessivaldo Rodrigues Galvão

ORCID: https://orcid.org/0000-0003-4242-6555 Universidade Federal Rural da Amazônia, Brazil E-mail: jessigalvao50@gmail.com

Rubson da Costa Leite

ORCID: https://orcid.org/0000-0002-3572-7600 Universidade Federal Rural da Amazônia, Brazil *E-mail: rubsonif@gmail.com

Leonardo de Almeida Oliveira ORCID: https://orcid.org/0000-0002-5195-6622 Universidade Federal Rural da Amazônia, Brazil

E-mail: leonardoaaloliveira@gmail.com

Joel Correa de Souza

ORCID: https://orcid.org/0000-0003-3001-1635 Universidade Federal Rural da Amazônia, Brazil E-mail: joel.correa@ufra.edu.br

\begin{abstract}
The knowledge of the quantity and composition of the deposited biomass is useful to plan the nutrient management of cultivations in agroforestry systems. The objective of this work was to evaluate the production of biomass and litter in two agroforestry systems with organic and conventional cultivations of sour orange. The areas use models of orange production by monoculture and under agroforestry systems: the first agroforestry system is composed of rows of brazilian mahogany (Swietenia macrophylla K.) accompanied by double rows of orange trees (Citrus aurantium L.); the second system is composed of rows of ingá (Ingá edulis Mart.) accompanied by double rows of orange trees. A completely randomized design was used in a 10x2 factorial scheme, with 4 replications. The locations within the management systems were organized as follows: agroforestry system composed of mahogany trees; Ingá trees agroforestry system; conventional sour orange monoculture system. The areas that the biomass and litter were collected in the locations in the systems were: between plants in the row for cultivation of forest species that make up the system; between rows of the forest species row and orange cultivation row; between plants in the orange cultivation row; between rows of the double row of orange cultivation. Two periods were analyzed in the experiment: the months of lowest and highest rainfall. Agroforestry systems promoted greater biomass and litter to the soil compared to monoculture. In this way, they were configured as a beneficial practice for the soil in sour orange crops in the Brazilian Amazon.
\end{abstract}

Keywords: Citrus aurantium; Ingá edulis; Swietenia macrophylla.

\section{Resumo}

O conhecimento da quantidade e composição da biomassa depositada é útil para planejar a gestão de nutrientes dos cultivos em sistemas agroflorestais. O objetivo deste trabalho foi avaliar a produção de biomassa e de liteira em dois sistemas agroflorestais com cultivos orgânicos e convencionais de laranja azeda. As áreas utilizam modelos de produção de laranja por monocultura e sob sistemas agroflorestais: o primeiro sistema agroflorestal é composto de fileiras de mogno brasileiro (Swietenia macrophylla K.) acompanhadas de fileiras duplas de laranjeiras (Citrus 
aurantium L.); o segundo sistema é composto por filas de ingá (Ingá edulis Mart.) acompanhadas por filas duplas de laranjeiras. Um desenho completamente aleatório foi utilizado num esquema fatorial 10x2, com 4 repetições. Os locais dentro dos sistemas de gestão foram organizados da seguinte forma: Sistema agroflorestal composto por árvores de mogno; Sistema agroflorestal de árvores Ingá; sistema convencional de monocultura de laranja azeda. As áreas em que a biomassa e a liteira foram recolhidos dentro dos sistemas foram: entre plantas da fileira de cultivo das espécies florestais que compõem o sistema; entre as fileiras da fileira de espécies florestais e a fileira de cultivo de laranjas; entre as plantas da fileira de cultivo da laranja; entre as filas da fila dupla do cultivo da laranja. Dois períodos foram analisados na experiência: os meses de menor e maior precipitação. Os sistemas agroflorestais promoveram maior biomassa e mais liteira para o solo em comparação com a monocultura. Desta forma, elas foram configuradas como uma prática benéfica para o solo em cultivos de laranja azeda na Amazônia brasileira.

Palavras-chave: Citrus aurantium; Ingá edulis; Swietenia macrophylla.

\section{Resumen}

El conocimiento de la cantidad y composición de la biomasa depositada es útil para planificar la gestión de los nutrientes de los cultivos en los sistemas agroforestales. El objetivo de este trabajo fue evaluar la producción de biomasa y hojarasca en dos sistemas agroforestales con cultivos orgánicos y convencionales de naranja agria. Las zonas utilizan modelos de producción de naranjas de monocultivo y bajo sistemas agroforestales: el primer sistema agroforestal está compuesto por hileras de caoba brasileña (Swietenia macrophylla K.) acompañadas de hileras dobles de naranjos (Citrus aurantium L.); el segundo sistema se compone de hileras de ingá (Ingá edulis Mart.) acompañadas de hileras dobles de naranjos. Se utilizó un diseño completamente aleatorio en un esquema factorial 10x2 con 4 repeticiones. Los sitios dentro de los sistemas de gestión se organizaron de la siguiente manera: Sistema agroforestal compuesto por árboles de caoba; Sistema agroforestal de árboles Ingá; sistema convencional de monocultivo de naranjas amargas. Las zonas donde se recogió la biomasa y la hojarasca dentro de los sistemas fueron: entre las plantas de la fila de cultivo de las especies forestales que componen el sistema; entre las filas de la fila de especies forestales y la fila de cultivos de naranja; entre las plantas de la fila de cultivo de naranjas; entre las filas de la doble fila del cultivo de naranjas. En el experimento se analizaron dos períodos: los meses de menor y mayor precipitación. Los sistemas agroforestales promovieron una mayor biomasa y una mayor cantidad de hojarasca en el suelo en comparación con el monocultivo. De este modo, se configuraron como una práctica beneficiosa para el suelo en los cultivos de naranja agria en la Amazonia brasileña.

Palabras clave: Citrus aurantium; Ingá edulis; Swietenia macrophylla.

\section{Introduction}

The Citrus genus comprises several species cultivated with economic importance, including C. sinensis (sweet orange), C. reticulata (tangerine) and C. limon (lemon) (Xu et al., 2013). Global orange production in 2019 was 78 million metric tons, and Brazil is the world's largest producer with an expected production of 16.9 million metric tons in 2021 (Fao, 2019, Usda, 2021).

Citrus fruits, especially oranges, are an important human nutritional source, for example, of vitamin $\mathrm{C}$ (Xu et al., 2013). In addition, orange cultivation has a major impact on agricultural production and the brazilian economy (Conab, 2021). Commonly, orange cultivation occurs in a monoculture system, however, in recent years, rural producers have been adopting cultivation in arrangements of agroforestry systems to diversify the source of income and meet a demand for a more sustainable agriculture (Mvondo et al., 2019).

In this perspective, agroforestry systems are characterized by the cultivation of arboreal and agricultural species in the same area simultaneously (Stocker et al., 2020). In addition to the benefits mentioned above, agroforestry arrangements can promote better nutrition for plants in the system and improve the soil fertility. The biodiversity promoted by these systems mitigates the resources available to the pathogen, reducing its presence and damage, for example, non-host plants act as a physical barrier against pests, and can also affect the success of the contamination pathogen by mechanisms of alteration of the microclimate (Oro et al., 2012, Ratnadass et al., 2012, Mvondo et al., 2019).

In regards to soil quality, the tree species inserted in the agroforestry systems promote greater carbon deposition, nutrient recycling, renewal of deep soil layers and the reduction of the impact of rain on soil micro-aggregates (Stocker et al., 2020). The recycling of nutrients occurs due to the high deposition of biomass (leaves, branches, fruits and roots), providing 
increased nutrients available in the soil. In the Amazon region, phosphorus can be a key nutrient in a nutritional management program because it has a high immobilization in soils with high aluminum and iron content (Tao et al., 2017).

The knowledge of the quantity and composition of the deposited biomass is useful to plan the nutrient management of cultivations in agroforestry systems (Pérez-Flores et al., 2018). During the decomposition of the litter, nutrients are released into the soil, which can later be absorbed by the plants, being an important form of nutrition for them (Bradford et al., 2002). The quality of this litter depends on the plant species present, influencing the type of biomass, the stage and speed of decomposition of the materials. Therefore, the objective of this work was to evaluate the production of biomass and litter in two agroforestry systems with organic and conventional cultivation of sour orange (Citrus aurantium) in a region of the Brazilian Amazon.

\section{Methodology}

The study area is located in the municipality of Capitão Poço - Pará, Brazil, using citrus production models by monoculture and under agroforestry systems (Figure 1). The region is classified as Brazilian Amazon and has an "Am" climate, according to the Köppen International Classification (Alvarez et al., 2013). The soil in the experimental area was described in terms of its chemical parameters (Table 1).

Figure 1. Location of the study area (A), sketch of the 20-year agroforestry system with mahogany (B) and sketch of the 10year agroforestry system with ingá (C).
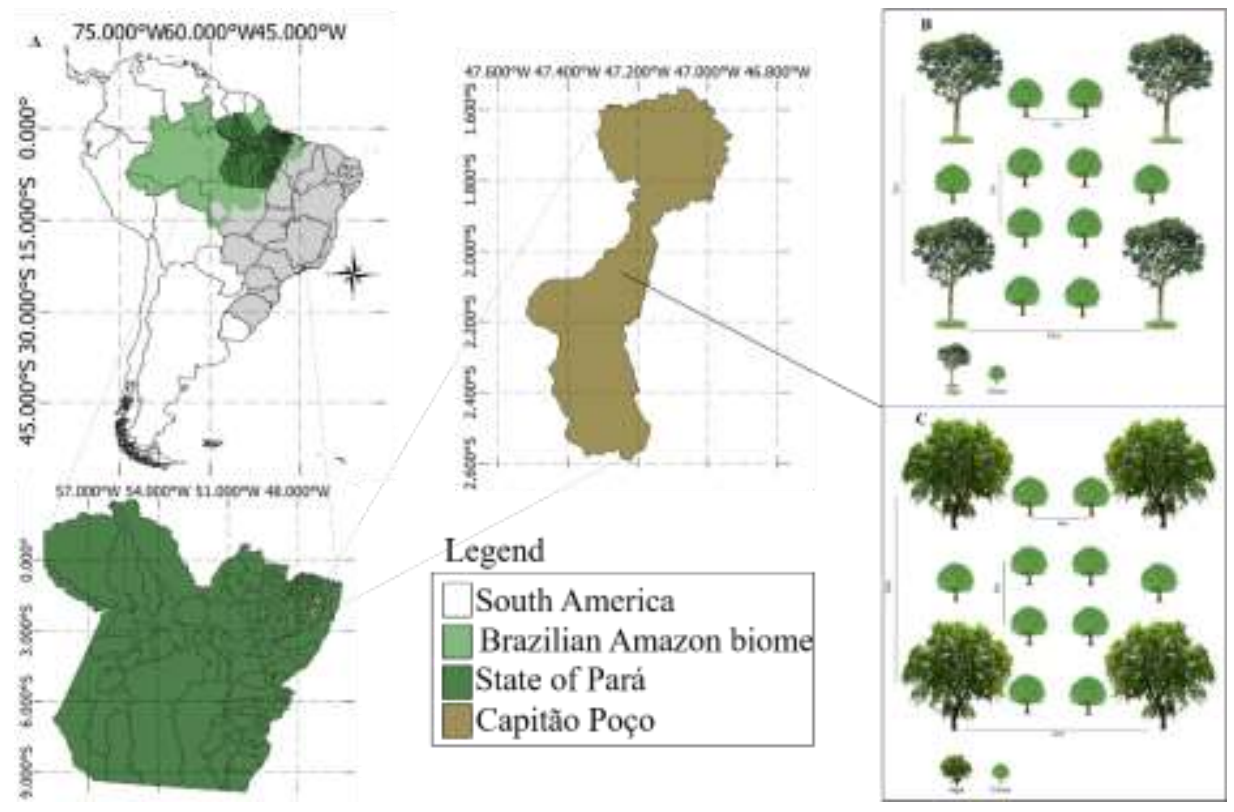

Source: Authors.

Table 1. Chemical characterization of soils under two agroforestry systems and orange monoculture area, at a depth of 0 to 20 $\mathrm{cm}$.

\begin{tabular}{|c|c|c|c|c|c|c|c|c|c|}
\hline System & $\begin{array}{l}\mathrm{pH} \\
\mathrm{H}_{2} \mathrm{O}\end{array}$ & $\begin{array}{l}\mathrm{Ca} \\
\ldots \ldots .\end{array}$ & $\begin{array}{l}\mathrm{Mg} \\
\mathrm{cmo}\end{array}$ & $\begin{array}{c}\mathrm{Al} \\
\mathrm{n}^{-3} \ldots\end{array}$ & $\begin{array}{l}\mathrm{H}^{+}+\mathrm{Al} \\
\ldots \ldots .\end{array}$ & $\underset{\mathrm{g} \mathrm{kg}^{-1}}{\mathrm{OM}}$ & $\begin{array}{l}\mathrm{P} \\
\ldots \ldots\end{array}$ & $\begin{array}{c}\mathrm{K} \\
\mathrm{n}^{-3} \ldots\end{array}$ & $\mathrm{C} / \mathrm{N}$ \\
\hline S1 & 4,6 & 0,9 & 0,3 & 0,6 & 4,3 & 14,5 & 5,3 & 25,8 & 12,5 \\
\hline S2 & 4,9 & 1,0 & 0,3 & 0,4 & 4,5 & 15,9 & 3,7 & 31,5 & 14,1 \\
\hline Monoculture & 4,6 & 0,7 & 0,2 & 0,6 & 3,7 & 12,3 & 5,9 & 17,8 & 15,4 \\
\hline
\end{tabular}

Agroforestry system 1 (S1): Agroforestry system with brazilian mahogany; Agroforestry system 2 (S2): Agroforestry system with ingá.; Source: Authors. 
A monoculture system was evaluated together with two agroforestry systems: the first agroforestry system (agroforestry system 1), with 10 ha, was implemented in 1997 through the system of cutting and burning for the production of swiddens. The arrangement of the system is made up of rows of brazilian mahogany (Swietenia macrophylla K.) accompanied by double rows of orange trees (Citrus aurantium L.); the second agroforestry system (agroforestry system 2) (8 ha) was implemented in 2007, composed of rows of ingá (Ingá edulis Mart.) accompanied by double rows of orange trees. In both areas there was a biomass management and organic fertilization with bovine manure until 2013. From 2013, only the biomass management was used. The area under conventional orange monoculture had been worked on for over 10 years, using fertilizers and pesticides to maintain production. The spacing used is $7 \mathrm{~m}$ between rows and $5 \mathrm{~m}$ between plants, fertilized with the NPK formulation 20-20-20, calculated at $340 \mathrm{~kg} \mathrm{ha}^{-1}$, following the needs according to the soil analysis of the area. Previously, dolomitic limestone was applied in annual applications at the beginning of the rainy season, applied to the cultivation line in the amount of $2 \mathrm{tha}^{-1}$.

A completely randomized design in a 10x2 factorial scheme was used, with 4 replications. The locations within the management systems were organized as follows: S1: agroforestry system with 20 years of age and composed of mahogany (Swietenia macrophylla K.) and orange trees (Citrus aurantium L.); S2: agroforestry system with 10 years of implantation and composed of Ingá (Ingá edulis Mart.) and orange trees; S3: conventional citrus monoculture system; The areas that the biomass and litter were collected in the locations in the systems were: L1: between plants in the row for cultivation of forest species that make up the system; L2: between rows of the forest species row and citrus cultivation row; L3: between citrus row plants; L4: between rows of the double row of citrus cultivation. Two periods were analyzed in the experiment: November 2016 and March 2017, the lowest (LP) and highest (HP) rainfall rates months, respectively (FigURE 2), in order to verify the influence of climate on production and chemical composition of biomass and litter capable by the systems. The treatments of the first factor are prepared according to Table 2 .

Figure 2. Average of the last 7 years (2011-2017) of precipitation in the municipality of Capitão-Poço, Pará, Brazil. Source: INMET.

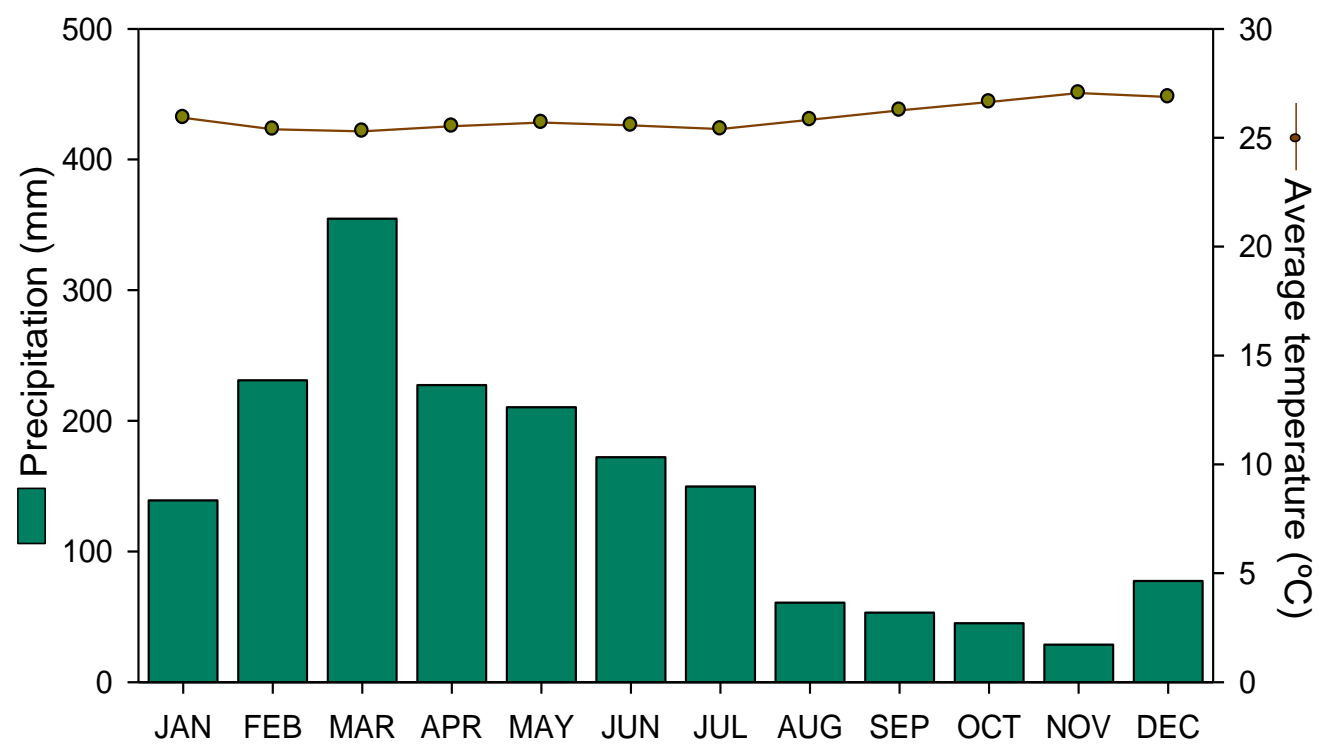

Source: Authors. 
Table 2. Description of the distribution of treatments according to the cultivation systems and the areas that the biomass and litter were collected.

\begin{tabular}{|c|c|}
\hline \multicolumn{2}{|r|}{ Treatments } \\
\hline S1L1 & between mahogany row plants \\
\hline S1L2 & between rows of mahogany row and row of orange cultivation \\
\hline S1L3 & between plants in the citrus cultivation row in agroforestry system 1 \\
\hline S1L4 & between rows of the double row of orange cultivation in agroforestry system 1 \\
\hline S2L1 & between plants in the ingá cultivation row \\
\hline S2L2 & between rows of the ingá row and the orange cultivation row \\
\hline S2L3 & between plants in the citrus cultivation row in agroforestry system 2 \\
\hline S2L4 & between rows of the double row of orange cultivation in agroforestry system 2 \\
\hline S3L1 & between plants in the row of orange cultivation \\
\hline S3L2 & between rows in the orange cultivation \\
\hline
\end{tabular}

\section{Source: Authors.}

Biomass and litter parameters deposited at the sampled points were evaluated using the following variables: humidity, production and dry mass. The samples were collected using a metal template measuring $0.5 \times 0.5 \mathrm{~m}$, with an area of $0.25 \mathrm{~m}^{2}$. The collection points were distributed in the systems according to the treatments mentioned above.

For biomass, all living plant individuals were collected, through a basal cut at the height of the soil. While for litter, all the decomposing matter above the ground was scraped. From each duly weighed sample, sub-samples of $100 \mathrm{~g}$ each were taken, stored in properly identified paper bags. To obtain the dry mass, this material was placed in a circulation oven and forced air renovation at $60{ }^{\circ} \mathrm{C}$ until it reached constant weight. Thus, production data for fresh biomass, dry biomass was obtained and the difference in values was described as humidity.

Initially, the data were assessed for normality and homoscedasticity. Subsequently, they were subjected to analysis of variance and, when significant, their means compared by the Scott-Knott test at $5 \%$ probability.

\section{Results}

There was a significant interaction between the factors for all variables analyzed. Regardless of the sampling point, the agroforestry systems had higher litter and biomass moisture.

During the period of lower precipitation (LP), the conventional system showed a lower percentage of humidity ( $\mathrm{p}$ $<0.05$ ) when compared to the agroforestry systems (Table 3). As for the sampled place, during the dry period the percentage of humidity was higher in treatments where there is greater proximity to the cultivation lines, and those between lines of C. aurantium showed a lower percentage of moisture. In the conventional production area, the cultivation line showed a higher percentage of moisture in the litter and biomass when compared to between cultivation lines. Comparing the periods, the highest average percentage of humidity was observed for the period of greatest precipitation (Table 3 ). 
Table 3. Litter and biomass moisture in agroforestry systems and conventional cultivation with sour orange.

\begin{tabular}{lcccc}
\hline Treatment & \multicolumn{2}{c}{ Litter moisture $(\%)$} & \multicolumn{2}{c}{ Biomass Moisture $(\%)$} \\
\cline { 2 - 5 } & $\mathrm{LP}$ & $\mathrm{HP}$ & $\mathrm{LP}$ & $\mathrm{HP}$ \\
\hline S1L1 & $71,75 \mathrm{Ba}$ & $74,15 \mathrm{Aa}$ & $51,66 \mathrm{Ba}$ & $60,02 \mathrm{Aa}$ \\
S1L2 & $67,14 \mathrm{Bb}$ & $71,07 \mathrm{Ab}$ & $49,75 \mathrm{Aa}$ & $51,09 \mathrm{Ac}$ \\
S1L3 & $70,03 \mathrm{Aa}$ & $70,47 \mathrm{Ab}$ & $49,54 \mathrm{Aa}$ & $50,78 \mathrm{Ac}$ \\
S1L4 & $66,48 \mathrm{Ab}$ & $67,04 \mathrm{Ac}$ & $27,63 \mathrm{Bd}$ & $39,00 \mathrm{Ad}$ \\
S2L1 & $71,74 \mathrm{Ba}$ & $75,57 \mathrm{Aa}$ & $53,33 \mathrm{Ba}$ & $63,19 \mathrm{Aa}$ \\
S2L2 & $71,27 \mathrm{Aa}$ & $72,15 \mathrm{Ab}$ & $44,33 \mathrm{Bb}$ & $53,27 \mathrm{Ab}$ \\
S2L3 & $70,09 \mathrm{Ba}$ & $74,34 \mathrm{Aa}$ & $49,70 \mathrm{Ba}$ & $54,62 \mathrm{Ab}$ \\
S2L4 & $59,63 \mathrm{Bc}$ & $63,64 \mathrm{Ad}$ & $40,08 \mathrm{Bc}$ & $54,84 \mathrm{Ab}$ \\
S3L1 & $55,31 \mathrm{Bd}$ & $63,31 \mathrm{Ad}$ & $26,72 \mathrm{Bd}$ & $34,83 \mathrm{Ae}$ \\
S3L2 & $49,00 \mathrm{Be}$ & $61,23 \mathrm{Ae}$ & $19,92 \mathrm{Be}$ & $25,47 \mathrm{Af}$ \\
\hline
\end{tabular}

*HP= high precipitation; $\mathrm{LP}=$ low precipitation; ** Means followed by the same lower-case letter in the column and upper case in the row. do not differ, by the Scott-Knott test, at 5\% probability.; Source: Authors.

The highest values of humidity were observed in the managements located in the areas of agroforestry system, with the exception of the managements S1L2, S1L4 and S2L4, which obtained lower averages when compared to the other treatments in the area of agroforestry systems. However, all treatments located in areas of agroforestry systems were superior to treatments in areas of conventional cultivation of C. aurantium. It is observed that the areas that most retained moisture within the evaluated agroforestry systems, are the areas closest to the arboreal individuals, S1L1, S1L3, S2L1, S2L2 and S2L3. The lowest concentrations of moisture found for litter and biomass in both agroforestry systems, occurred in the treatment S1L4 and S2L4, followed by the treatments contained in the area of orange monoculture, areas which are less influenced by the presence of forest species within the systems.

The humidity values, in general, were higher in the period of greater precipitation. Only treatments S1L3, S1L4 and S2L2 were the same in both periods of collection. For biomass, only the treatments S1L2 and S1L3 were the same, regardless of the time of collection, which can be attributed to the greater amount of spontaneous vegetation, which favors the retention of moisture above the ground due to greater shading and protection of the soil.

In general, the production of fresh litter mass showed higher production in the S2L2 treatment in the period of lower precipitation (Table 4). For the period of greatest rainfall, the treatments S1L1, S1L2 and S2L2 obtained superior fresh mass production. For the production of fresh biomass mass, the treatment S1L1, S1L3 and S2L2 were similar, obtaining higher yields in the period of lower precipitation (LP), while in the period of greater precipitation, treatment S1L3 showed higher production.

Table 4. Production of litter and biomass in agroforestry systems and conventional cultivations cultivated with Citrus.

\begin{tabular}{lrrrr}
\hline \multirow{2}{*}{ Treatment } & \multicolumn{2}{c}{ Litter production $\left(\mathrm{kg} \mathrm{ha}^{-1}\right)$} & \multicolumn{2}{c}{ Biomass production $\left(\mathrm{kg} \mathrm{ha}^{-1}\right)$} \\
\cline { 2 - 5 } & $\mathrm{LP}$ & $\mathrm{HP}$ & \multicolumn{1}{c}{$\mathrm{LP}$} & $\mathrm{HP}$ \\
\hline S1L1 & $10233 \mathrm{Ac}$ & $8700 \mathrm{Ba}$ & $10920 \mathrm{Ba}$ & $16900 \mathrm{Ab}$ \\
S1L2 & $9452 \mathrm{Ad}$ & $8184 \mathrm{Ba}$ & $8810 \mathrm{Bb}$ & $14730 \mathrm{Ac}$ \\
S1L3 & $8087 \mathrm{Ae}$ & $6540 \mathrm{Bb}$ & $10810 \mathrm{Ba}$ & $23200 \mathrm{Aa}$ \\
S1L4 & $6020 \mathrm{Ag}$ & $5400 \mathrm{Ac}$ & $5710 \mathrm{Bc}$ & $8650 \mathrm{Ad}$ \\
S2L1 & $12463 \mathrm{Ab}$ & $5850 \mathrm{Bc}$ & $8050 \mathrm{Ab}$ & $6713 \mathrm{Be}$ \\
S2L2 & $16272 \mathrm{Aa}$ & $8245 \mathrm{Ba}$ & $10136 \mathrm{Ba}$ & $14812 \mathrm{Ac}$ \\
S2L3 & $9302 \mathrm{Ad}$ & $5492 \mathrm{Bc}$ & $7662 \mathrm{Bb}$ & $12200 \mathrm{Ac}$ \\
S2L4 & $6947 \mathrm{Af}$ & $4303 \mathrm{Bd}$ & $4677 \mathrm{Bc}$ & $11430 \mathrm{Ac}$ \\
S3L1 & $1000 \mathrm{Ac}$ & $2865 \mathrm{Be}$ & $350 \mathrm{Ae}$ & $1186 \mathrm{Af}$ \\
S3L2 & $7572 \mathrm{Ae}$ & $2215 \mathrm{Be}$ & $575 \mathrm{Ae}$ & $1744 \mathrm{Af}$ \\
\hline
\end{tabular}

$* \mathrm{HP}=$ high precipitation; $\mathrm{LP}=$ low precipitation; ** Means followed by the same lower-case letter in the column and upper case in the row. do not differ, by the Scott-Knott test, at 5\% probability.; Source: Authors. 
The production of fresh mass in the litter was higher in the period of lower precipitation (LP), in biomass the highest values were observed when there was a higher incidence of rainfall (HP) (Table 4).

In the period of lower precipitation, the production of fresh biomass was higher in the S2L2 treatment and for litter in the S2L2, S1L1 and S1L3 treatments. In the period of greatest precipitation, the treatments S1L1, S1L2 and S2L2 were superior for litter production and for biomass the treatment S1L3 was superior. The lower production of biomass and litter in both periods of evaluation, were observed in the treatments located in the areas of monoculture of citrus (S3L1 and S3L2).

The higher production of litter in the agroforestry system 2, in both periods, is related to the deposition of residues by herbaceous plants, which suffer more intensely from the external abiotic effects. The agroforestry system 1 , with the presence of large tree species, provides the system with greater shading and a consequent reduction in stress caused by excess light, reducing losses of plant biomass production.

The production of dry mass from the litter showed a significant difference between the treatments studied (Table 5). The treatment S2L2 was superior in the period of less precipitation, whereas the treatment S3L1 was superior in the period of greater precipitation. The increase in litter production in the S2L2 treatment is due to the beneficial effects promoted by the forest species (Ingá edulis Mart.) Implanted in the system, which provides greater fixation of atmospheric nitrogen to the soil. A higher production of litter in between cultivation lines was observed in comparison to the cultivation lines, possibly due to the excessive competition for resources such as water and nutrients and excessive shading caused by the presence of the tree species in the system.

Table 5. Production of litter dry matter and biomass dry matter in agroforestry systems and conventional cultivations cultivated with Citrus.

\begin{tabular}{lcccr}
\hline Treatment & \multicolumn{2}{c}{ Litter dry matter $\left(\mathrm{kg} \mathrm{ha}^{-1}\right)$} & \multicolumn{2}{c}{ Biomass dry matter $\left(\mathrm{kg} \mathrm{ha}^{-1}\right)$} \\
\cline { 2 - 5 } & $\mathrm{LP}$ & $\mathrm{HP}$ & $\mathrm{LP}$ & $\mathrm{HP}$ \\
\hline S1L1 & $2896 \mathrm{Ad}$ & $2246 \mathrm{Bc}$ & $5274 \mathrm{Ba}$ & $6765 \mathrm{Ab}$ \\
S1L2 & $3102 \mathrm{Ac}$ & $2367 \mathrm{Bc}$ & $4427 \mathrm{Bb}$ & $7199 \mathrm{Ab}$ \\
S1L3 & $2425 \mathrm{Ae}$ & $1932 \mathrm{Bd}$ & $5457 \mathrm{Ba}$ & $11391 \mathrm{Aa}$ \\
S1L4 & $2017 \mathrm{Af}$ & $1780 \mathrm{Ae}$ & $4132 \mathrm{Bb}$ & $5283 \mathrm{Ac}$ \\
S2L1 & $3523 \mathrm{Ab}$ & $1428 \mathrm{Be}$ & $3750 \mathrm{Ab}$ & $2477 \mathrm{Bd}$ \\
S2L2 & $4675 \mathrm{Aa}$ & $2297 \mathrm{Bc}$ & $5642 \mathrm{Ba}$ & $6918 \mathrm{Ab}$ \\
S2L3 & $2787 \mathrm{Ad}$ & $1409 \mathrm{Be}$ & $3856 \mathrm{Bb}$ & $5494 \mathrm{Ac}$ \\
S2L4 & $2804 \mathrm{Ad}$ & $1564 \mathrm{Be}$ & $2802 \mathrm{Bc}$ & $5173 \mathrm{Ac}$ \\
S3L1 & $1280 \mathrm{Bg}$ & $3774 \mathrm{Aa}$ & $256 \mathrm{Ad}$ & $774 \mathrm{Ae}$ \\
S3L2 & $1125 \mathrm{Bg}$ & $2938 \mathrm{Ab}$ & $430 \mathrm{Bd}$ & $1396 \mathrm{Ae}$ \\
\hline
\end{tabular}

$* \mathrm{HP}=$ high precipitation; $\mathrm{LP}=$ low precipitation; ** Means followed by the same lower-case letter in the column and upper case in the row. do not differ, by the Scott-Knott test, at 5\% probability.; Source: Authors.

For assessments of biomass dry mass production, in general, the treatments present in agroforestry system 1 obtained higher yields for both assessment periods (Table 5). Depending on the time of collection, the highest averages of biomass production were observed in the period of greatest precipitation.

\section{Discussion}

The Amazon rainforest is the largest tropical forest in the world, with several ecological benefits for the planet, such as, for example, fundamental environmental services related to water; sequestration of atmospheric CO2 and diversity of animals, plants and microorganisms (Bendel \& Stephens 2020, Casagrande et al., 2021, Souza et al., 2021). Currently, this forest is constantly threatened by changes in land use, in particular by deforestation (Casagrande et al., 2021). From this point of view, it is essential to study management systems that promote sustainable land use in these regions, enabling economic 
exploitation by the inhabitants of the region, but with the least possible impact on natural resources.

The increase in volume and good dispersion of rainfall in the region (approximately $300 \mathrm{~mm}$ ) favored the increase in humidity in the evaluated agroforestry systems (Table 3). However, the moisture content found in the litter and biomass collected in both systems did not reach values below 59.63\% and $63.64 \%$ for litter and below $23.67 \%$ and $39 \%$ for biomass in the periods of smaller and larger precipitation, respectively. These high humidity values, when compared to treatments located in conventional cultivation areas, may be related to the high-water retention capacity of the studied agroforestry systems.

The fact that the treatments located in the double row of oranges line obtain lower percentages of humidity, may be related to greater exposure to solar radiation (due to the lower shading effect promoted by the crowns), promoting greater water loss through the transpiration processes, which reduces the moisture found in the biomass and litter produced in these areas (Taiz et al., 2017, Gazolla-Neto et al., 2013).

The presence of arboreal individuals in production systems promotes benefits, such as greater floristic wealth, which causes greater production of vegetation cover, reallocation of nutrients from deeper layers, normally unexplored from the soil, to plants, which occurs through deposition of fruits, flowers, leaves, branches and other plant parts, providing greater land use efficiency (Kotowska et al., 2016).

For conventional cultivation, the average humidity in the biomass and litter were higher in the period of greater precipitation, possibly due to the eradication of the diversity of natural vegetation and the absence of tree individuals in the production environment, which disadvantages factors such as shading, protection of soil, water retention and better use of water in the system (Kotowska et al., 2016).

The results of the present study corroborate with those found in the literature, where litter production is higher when there is greater humidity, regardless of the biome to be studied, and that the volume of precipitation affects biomass with less stability in a more severe way when compared to forests. (Tonin et al., 2017, Costa et al., 2017).

Vegetable remains deposited on the soil are important in the process that determines the carbon and nutrient cycling of forest ecosystems; it controls the main breathing substrates in forest soil and maintains soil fertility and organic matter (Schlesinger \& Andrews 2000, Hansen et al., 2009, Zhang et al., 2014).

In general, as for the collection period, the highest production for biomass was observed at the end of the period of greatest precipitation. For litter, there is an inversely proportional relationship, when there is an increase in rainfall, there is a decrease in the litter accumulated above the ground, possibly accelerating the decomposition of retained material. The litter production, for all treatments, was higher in the period of lower precipitation, which may be due to the low availability of water resources, promoting greater leaf senescence, in an attempt to reduce water loss through the plant's photosynthesis process. Growth efficiency may be related to the ability of plants to adapt to the light conditions of the environment, with the satisfactory growth of some species in environments with low or high light attributed to the species' ability to quickly adjust its biomass allocation model and physiological behavior (Poorter et al., 2019).

Studying the production and characterization of a litter in a Virola surinamensis cultivation area and in a successional forest, Costa et al. (2017) concluded that the forest area in relation to the cultivation area presented higher values of dry matter production, concluding that the diversity of species in the forest area favored the increase of litter production.

The maximum and minimum litter production were $16,272.5 \mathrm{~kg} \mathrm{ha}^{-1} 6,947.5 \mathrm{~kg} \mathrm{ha}^{-1}$, respectively. In addition to the variety and abundance of species, the reduction of intense radiation reaching the soil surface may have favored the increase in the production of litter and biomass in agroforestry systems, when related to the monoculture system, which shows that the composition and presence of arboreal individuals in the studied agroforestry systems were fundamental for the increase of these variables. Studying the effects of light intensity, Gazolla-Neto et al. (2013) observed that in about 35\% of availability, the production of leaves of Solanum americanum was favored, however at an availability of $65 \%$ and under full light (100\%) there 
was a reduction in the production of fresh and dry leaf mass.

When assessing the accumulation of biomass and litter in six legume species, among them ingá, in comparison to the native forest in the Peruvian Amazon, Szott et al. (1994) mention that for 53 months the production of biomass in the areas that contained ingá obtained biomass production similar to the native area, attributing the good results to the rapid growth of the legume. Our results demonstrate that the use of brazilian mahogany presents more promising results regarding the production of biomass above ground.

Ingá plants have rapid growth, promote the suppression of aggressive grasses, have high litter productivity, provide soil protection and greater availability of nutrients (Celentano et al., 2011). In contrast, the leaves of this species have a high recalcitrant fraction and a low relative rate of decomposition.

For litter, the highest yields occurred in the period of lowest rainfall, an inversely proportional relationship, when there is an increase in rainfall, there is a decrease in the litter accumulated above the soil. These data are similar to those found by Fernandes and Scaramuzza (2007), who observed different values of annual litter production, attributed to the variation of the tree components of the systems, which presented varied water retention capacities and consequent production.

For all the treatments observed, with the exception of those that make up the monoculture (S3L1 and S3L2), the litter production was higher in the period of lower precipitation, a factor that promotes leaf loss, in an attempt to reduce water loss by photosynthetic processes of the plant. The water deficit in the soil has a great relationship with the production of litter, that is, the low availability of water in the soil causes the plant to activate its water saving mechanisms, one of which is the elimination of part of the foliage (Poorter et al., 2019).

The difference observed for the production of litter and biomass between the systems is related to the tree species implanted in these agroforestry systems, which present different phenological behaviors and, consequently, differentiated production. Evaluating the litter production of 32 species individually, Zalamea and González (2008) observed that each species presented different characteristics of litter production, even under similar edaphoclimatic conditions.

The decomposition of litter in regions such as in the Brazilian Amazon (humid tropical) is accelerated and quickly supplies nutrients to the soil, but there is a high variation in the quantity, quality and decomposition of this litter (Zhang et al., 2014, Correia et al., 2018). This is due to several factors, including rainfall and the type of species that make up the area. In fact, our results showed that there is a significant difference between the species that make up the agroforestry systems and the period evaluated. Additionally, we observed that this variation is still due to the spot collected within the system.

According to Zhang et al. (2014), the amount of litter deposited in the soil is regulated by different factors worldwide. For example, in temperate forests they mention that temperature and radiation are major factors in regulating the amount of litter. In tropical forests, precipitation and radiation dominate the seasonality of litter fall in the soil, corroborating our results.

In comparison with the adoption of agroforestry systems, the area of single orange cultivation showed much lower values for the production of biomass and litter, which shows that the composition and presence of tree individuals in the studied agroforestry systems was fundamental for the increase of biomass production and litter at all collection sites within each system (Gazolla-Neto et al., 2013).

Excessive solar radiation can impair growth by negatively influencing photosynthesis and increasing respiratory rate, reducing liquid photosynthesis and the increase in plant biomass (Taiz et al., 2017). Thus, it can be justified that the absence of shading was detrimental to the production of biomass in the evaluated conditions.

Our results provide important information regarding the adoption of agroforestry systems and forest species used in sour orange cultivation in the Amazon region. We recommend further studies regarding the quality of the deposited biomass, more soil quality parameters and the use of other forest species. 


\section{Conclusions}

Agroforestry systems promoted greater biomass and litter to the soil compared to the monoculture of orange. In this way, they were configured as a beneficial practice for the soil in sour orange crops in the Brazilian Amazon.

The litter production was higher in the agroforestry system with the presence of I. edulis, in the cultivation line. The period of lower precipitation promoted a greater production of dry mass of litter and biomass.

\section{Acknowledgments}

The authors acknowledge the financial support from Coordination for the Improvement of Higher-Level Personnel (CAPES-Brazil). To the National Council for Scientific and Technological Development (CNPq-Brazil) and the Graduate Program in Agronomy (PGAgro-UFRA).

\section{References}

Alvares, C. A., Stape, J. L., Sentelhas, P. C., Goncalves, J. L. M. \& Sparovek, G. (2013). Koppen's climate classification map for Brazil. Meteorologische Zeitschrift, 22, 711-728.

Bendel, J. \& Stephens, T. (2020). Turning to international litigation to protect the Amazon? RECIEL. Early View.

Bradford, M. A., Jones, T. H., Bardgett, R. D., Black, H. I. J., Boag, B. \& Bonkowski, M. et al. (2002). Impactos de la composición de las comunidades de fauna del suelo en los ecosistemas de pastizales modelo. Science, 298, 615-617.

Casagrande, E., Recanati, F., Rulli, M. C., Bevacqua, D. \& Melia, P. (2021). Water balance partitioning for ecosystem service assessment. A case study in the Amazon. Ecological Indicators, 121, 107-155.

Celentano, D., Zahawi, R. A., Finegan, B., Casanoves, F., Ostertag, R., Cole, R. J. \& Holl, K. D. (2011). Restauración ecológica de bosques tropicales en Costa Rica: efecto de varios modelos en la producción, acumulación y descomposición de hojarasca. Revista de Biología Tropical, 5(3), 1323-1336.

CONAB. (2021). Companhia Nacional de Abastecimento. Laranja - Análise mensal. Brasília: Conab. http://www.conab.gov.br

Costa, B. C., Suzuki, P. M., Martins, W. B. R., Andrade, V. M. S. \& Oliveira, F. A. (2017). Dinâmica da massa seca e propriedades químicas da liteira em Virola surinamensis e floresta sucessional na Amazônia oriental. Revista Verde de Agroecologia e Desenvolvimento Sustentável, 12 (1), 23-28.

Correia, R. G., Martins, W. B. R., Oliveira, F. A., Dionisio, L. F. S., Neves, R. L. P. \& Batista, T. F. V. (2018). Production and decomposition of litter in different mahogany (Swietenia macrophylla King) cropping systems. Brazilian Journal of Wood Science, 9(2), $103-110$.

FAO. (2021). Food and Agriculture Organization of the United Nations. Production quantities of Oranges by country. http://www.fao.org/

Fernandes, F. C. S. \& Scaramuzza, W. L. M. P. (2007). Produção e decomposição de liteira em fragmento florestal em Campo Verde, MT. Revista de Ciências Agrárias, 1(1).

Gazolla-Neto, A., Aumonde, T. Z., Pedó, T., Olsen, D. \& Villela, F. A. (2013). Ação de níveis de luminosidade sobre o crescimento de plantas de mariapretinha (Solanum americanum Mill.). Revista Brasileira de Biociências, 11(1), 88-92.

Hansen, K., Vesterdal, L., Schmidt, I. K., Gundersen, P., Sevel, L., Basturp-Birk, A., Pedersen, L. B. \& Bille-Hansen, J. (2009). Litterfall and nutrient return in five tree species in a common garden experiment. Forest Ecology and Management, 257, 2133-2144.

Kotowska, M. M., Leuschner, C., Triadiati, T. \& Hertel, D. (2016). Conversion of tropical lowland forest reduces nutrient return through litterfall and alters nutrient use efficiency and seasonality of net primary production. Oecologica, 180, 601-618.

Mvondo, E. A., Ndo, E. G. D., Bieng, M. A. N., Ambang, Z., Manga, B., Cilas, C., Manga, M. L. T. \& Nomo, L. B. (2019). Assessment of the interaction between the spatial organization of citrus trees populations in cocoa agroforests and Phytophthora foot rot disease of citrus severity. Agroforestry System, 93 , 493-502.

Oro, F. Z., Bonnot, F., Ngo-Bieng, M. A., Delaitre, E., Dufour, B. P., Ametefe, K. E., Mississo, E., Wegbe, K., Muller, E. \& Cilas, C. (2012). Spatiotemporal pattern analysis of Cacao swollen shoot virus in experimental plots in Togo. Plant Pathology, 61(6), 1043-1051.

Perez-Flores, J., Perez, A. A., Suarez, Y. P., Bolaina, V. C. \& Quiroga, A. L. (2018). Leaf litter and its nutrient contribution in the cacao agroforestry system. Agroforestry System, 92, 365-374.

Poorter, H., Niinemets, U., Ntagkas, N., Siebenkas, A., Maarit, M., Matsubara, S. \& Pons, T.L. (2019). A meta-analysis of plant responses to light intensity for 70 traits ranging from molecules to whole plant performance. New Phytologist, 223, 1073-1105.

Ratnadass, A., Fernandes, P., Avelino, J. \& Habib, R. (2012). Plant species diversity for sustainable management of crop pests and diseases in agroecosystems. Agronomy for Sustainability Development, 32, (1), 273-303.

Schlesinger, W. H. \& Andrews, J. A. (2000). Soil respiration and the global carbon cycle. Biogeochemistry, 48, 7-20. 
Research, Society and Development, v. 10, n. 5, e41110515165, 2021

(CC BY 4.0) | ISSN 2525-3409 | DOI: http://dx.doi.org/10.33448/rsd-v10i5.15165

Souza, F. F. C., Mathai, P. P., Pauliquevis, T., Balsanelli, E., Pedrosa, F. O. \& Souza, E. M. (2021). Influence of seasonality on the aerosol microbiome of the Amazon rainforest. Science of the Total Environment, 760(144092).

Stocker, C. M., Bamberg, A. L., Stump, L., Monteiro, A. B., Cardoso, J. H. \& Lima, A. C. R. (2020). Short-term soil physical quality improvements promoted by an agroforestry system. Agroforestry System, 94, 2053-2064.

Szott, L. T., Palm, C. A. \& Davey, C. B. (1994). Biomass and litter accumulation under managed and natural tropical fallows. Forest Ecology and Management, 67, 177-190.

Taiz, L., Zeiger, E., Moller, I. \& Murphy, A. (2017). Plant physiology and development. (6a ed.), Artmed.

Tao, J., Liu, X., Liang, Y., Niu, J., Xiao, Y. \& Gu, Y., et al. (2017). Maize growth responses to soil microbes and soil properties after fertilization with different green manures. Applied Microbiology and Biotechnology, 101, 1289-1299.

Tonin, A. M., Gonçalves, J. F., Bambi, P., Couceiro, S. R. M., Feitoza, L. A. M. \& Fontana, L. E. et al. (2017). Plant litter dynamics in the forest-stream interface: precipitation is a major control across tropical biomes. Scientific Reports, 7(e10799).

USDA. (2021). United States Department of Agriculture. Citrus: World Markets and Trade. Foreign Agricultural Service. Available in: https://www.usda.gov/

Xu, Q., Chen, L., Ruan, X., Chen, D., Zhu, A. \& Chen, C. et al. (2013). The draft genome of sweet orange (Citrus sinensis). Nature Genetics, $45(1)$, 59-67.

Zalamea, M. \& González, G. (2008). Leaffall phenology in a subtropical wet forest in Puerto Rico: from species to community patterns. Biotropica, 40(3), 295-304.

Zhang, H., Yuan, W., Dong, W. \& Liu, S. (2014). Seasonal patterns of litterfall in forest ecosystem worldwide. Ecological Complexity, $20,240-247$. 